\title{
SPATIAL DEUELOPMENT AND ITT POLICIES AS GOHESION MEANS IN THE EU AND TURKEY
}

\author{
Mehmet C. Marin \\ Kahramanmaraş Sütçü Imam Üniversitesi \\ Iktisadi ve Idari Bilimier Fakültesi
}

\section{$A B$ ve Türkiye'de Bütünleşmenin Bir Aracı Olarak Mekansal Gelişme ve BiT Politikalart \\ Özet}

Zamanla politik, cografik, ekonomik ve sosyal boyutlarıyla giderek daha kompleks bir birlik haline gelen $A B$, yeni üyelerin kabuliuyle birlikte artan yeni bir mekansal sosyoekonomik kisitlamalar dilemmasıyla yüz yüze kaldı. Gelirin mekansal dağlımındaki farklılıkłarın, yoksul bölgelerden göreceli daha zengin bölgelere istenmeyen yeni gö̧̧lere yol açabilme ve ekonomik aktivitelerin yer seçimlerini etkileyebilme potansiyeli nedeniyle, bölgesel gelir farklıhklan bütünleșme ve uyumlaşma süreçlerinin başanıya ulaşmasım kısıtlayan bir engel olarak algılandı. Çünkü sonuçta bu faktörler, $A B$ üyesi ülke ve bölgeleri arasında tansiyon ve çelişkiler yaratarak birligin politik varlığmı da tehdit edebilirlerdi. $\mathrm{AB}$, mekansal gelişme ve BIT politikalarının sosyoekonomik bütünleşmesini saglamak ve küresel ekonomide rekabet edebilme kapasitesini etkili bir şekilde artırmak için kentsel ve bölgesel gelişme çabalarını hayati bir parçası olarak görmektedir. Bu makalede, AB ve Türkiye'nin kentsel ve bölgesel kalkınmadaki mekansal gelişme ve BìT politikalan karşılaştınlmaktadır.

Anahtar Kelimeler: Avrupa Mekansal Gelişme Perspektifi, BIT, CEMAT, Türkiye, AB, sosyal uyum.

\section{Abstract}

As the EU has gradually evolved into a politically, geographically, economically and socially more complex unity, it has increasingly faced with the dilemma of spatial socioeconomic constraints produced by the added new member states. Regional differences in socioeconomic development was perceived as a barrier to further cohesion and integration processes, for spatial variation in income could result in undesirable population movements from the poor to rich regions and relocation of economic activities that in turn might thread to political viability of the EU through political tensions between regions. Hence, the union has viewed the development of spatial and ITT policies as a vital component of its urban and regional development efforts in order to effectively achieve the socioeconomic cohesion and capability to compete in an increasingly global market. Contrary to the EU, Turkey has long neglected to develop a region-based national policy with specific goals and objectives in the area of spatial development and ITT. This paper compares EU and Turkey's spatial development and ITT policies in urban and regional development. cohesion.

Anahtar Kelimeler: European Spatial Development Perspective, ITT, CEMAT, Turkey, EU, social 


\section{Spatial Development and ITT Policies as Cohesion Means in the EU and Turkey}

\section{Introduction}

As the European Union (EU) has gradually evolved into politically, economically and socially a more integrated entity, it has faced with the dilemma of increasing spatially-materialized socioeconomic variations between and within member states. Any additional new member to the union has ultimately led to a rise in this spatial variation. Spatial socioeconomic differences can have major impacts on the union's efforts toward integration by creating tensions between poor and rich member states through relocation of firms and populations in the long run. Furthermore, integration process requires the member states dissolve their traditional political geographic boundaries and redraw new functional regional lines in order to achieve various goals of the EU's policies. Besides, economic and political integration of the process necessitates some dramatic structural changes in traditional administrative and political systems that have historically been organized on geographical bases. Thus, geography does matter in the integration process and it can substantially affect the success of all political and economic objectives. Indeed, in an EU report, the ministers responsible for spatial planning in the member states and the EU's commission emphasize the significant role of developing a spatial development perspective as an integral part of all other policies toward the integration (ESDP, 1999).

From an economic point of view, space, a two dimensional surface of the earth, enters into economic relationships via transaction costs that result from physical separation of human activities and distribution of natural resources (BECKMANN, 1999: 1). For historical, accidental or economic reasons, different economic or human activities have unevenly distributed over the space (BOYCE, 1974: 1), giving rise to transaction costs that in return influence later human locational patterns. On the other hand, technological improvements in transportation, information, communication and production have extensively 
reduced spatial transaction costs over time, leading to relocation of production on a larger scale and increasing regional competition on a global level (ANGELL, 1995: 10). These later changes in the global economic restructure forced many countries and the EU to emphasize more on the role of Information and Telecommunication Technologies (ITT) in economic development policies.

The EU's spatial development and ITT policies target several intervening objectives at the same time: to facilitate socioeconomic and political cohesion of the union by overcoming previous geopolitical boundaries that prevented a functional economic integration of European regions, to minimize spatial socioeconomic differences that have so long put constraints on the successful implementation of various policies, to increase global competitiveness of the European regions by adopting ITT that reduce physical friction and thus spatial interaction costs, and to sustain a balanced economic growth throughout Europe (ESDP, 1999).

In this paper, an attempt will be made to develop a theoretical spatial framework to analyze how the EU uses a spatial development perspective and ITT policies to support the integration process and economic development. The remaining of the paper is structured as follows: first a theoretical spatial framework is introduced, followed by a discussion of the EU and Turkey's spatial development and ITT policies. The third section goes on to discuss potential implications of these policies for European regions and Turkey.

\section{Spatially-Crystallized Barriers to European Unionization: Toward a Spatial Approach of EU's Integration}

The EU's policies, regardless of their specific contexts, are carried out in space and hence required organization at different scales. For our purpose, a policy can be considered to have the following components: goals that a policy attempts to ultimately achieve, objectives specifically operationalized to reach to these goals and means that are utilized to conduct specific activities in order to realize defined objectives. Means, objectives or goals may directly or indirectly involve in place through utilization and transformation of the space for some purposes. For example, the EU's structural funds attempt to reduce spatial income gaps by transferring resources that ultimately transform previous socioeconomic conditions of some regions. Furthermore, one of major objective in the EU's ITT policies is to reduce spatial interaction costs. The Space and ITT are related. As HARVEY (1999: 235) notices "the capitalists cannot for 
long look to capture the benefits of technological change without forming fixed capital [built environment]". Therefore, a spatial approach is necessary to understand causes and processes generated by various geographic factors, ultimately creating barriers to the integration and further social cohesion.

This section develops a spatial framework latter applied to the discussion of the spatial development and ITT policies of the union and their counterparts in Turkey. For various reasons including, historical, cultural, economical, political and administrative, states have been divided into regions, sub-regions and even smaller urbanized areas to conduct everyday activities easier. However, as the political and economic integration of the EU's member states have deepen up since 1960s, the EU has increasingly been faced with the dilemma of spatial constraints that prevent successful implementation of various socioeconomic policies. As KOMORNICKI (2002) points out, even today the EU has around 50 different land borders with different regimes, compared to North America's only two different land borders and two regimes. Thus, the enlargement of the EU can have dramatics impact on the fiber of the European territory, especially at the internal and external border regions (ESPON, 2002: 3): first, most national and regional borders corresponding to previous administrative, economic and political realities of specific nations have lost their meanings in the face of new territorial and political requirements of the union. A new political and economic system, namely the EU; which has been increasing in territorial terms, necessitates the elimination of many previous national and regional boundaries at least in psychological and institutional terms in order to apply and spatially harmonize various policy instruments to a common European space. For example custom duties, taxes and exchange rates could not vary based on some national or regional territories, as it would lead to differences in spatial advantages or disadvantages. Secondly, European Unity requires some common political and administrative intuitions to organize on the geographical basis of the whole territory. Third, the integration, and thus the creation of a common market, also needs harmonization and reconfiguration of the European territory in order to reduce spatial interaction costs and achieve a balanced sustainable economic growth all over the common space. Finally, the elimination of spatial barriers in the union's territory was also perceived as a primary objective toward development of a competitive European Economic Space in an increasingly globalizing world market.

Indeed, the first chapter of the European Spatial development Perspective (ESDP) identifies territory or space as 'a new dimension' of the European policy. With the implementation of the European Monetary Union (EMU), it is no longer possible to compensate for productivity disparities through the simple 
adjustment of exchange rates. In fact, present disparities may get worse over time. The spatial balance the EU seeks out is expected to contribute to a more even geographic distribution of growth and to reconcile social and economic claims on land with its ecological and cultural functions (CSD, 1999: 7).

Human adaptation to and interaction with the physical environment implies the need for the development of a comprehensive theory of economy and society that embraces both temporal and spatial dimensions. Generally speaking, "economic evolution stems from the action of technological man upon the elements of his physical environment" (ISARD, 1956: vii-1). From a Marxist political economic perspective, spatial forms result from social processes that are inherently spatial (HARVEY, 1973: 10-11). Labor, capital, and money that make up basic units of capitalist economy move through space. While capitalism organizes space in its own image and according to its needs, the spatial organization is not merely a reflection of capital accumulation as shown by different organization of space that varies from place to place and from time to time. This implies that the space is also socially produced. In short, reconfiguration of space should be viewed as an active moment within temporal dynamics of accumulation and social reproduction. The explosion of knowledge and its impacts on production and human relations has given a new meaning to space and cities as invention, production and play fields (HARVEY, 1999: 374-376). There is a dialectical interaction process that arises between space and place-embedded social relations. Once determined by placeembedded social relations, however, the space can no longer be reduced to these social relations. In return, the space affects the future development of the social relations. For example, the urban space does not cause the formation of a working class consciousness, which is more a product of the conflict between the working class and capital. On the other hand, the concentration of workers in the urban space facilitates the formation of this consciousness (ŞENGÜL, 2001: 145-147).

To Lefebvre (1970: 28-32), the city is an arrangement of objects in space. While modes of production do not strictly correspond to space where they operate, each epoch requires a specific geographical reconfiguration to rationalize production. In the pre-industrial and agricultural age, the city performed a superstructural or political role, removed from the core of production. In the mercantile age, the city changed internally but its contextual environment remained the same and continued operating as a political entity, though with an added new trade function. By contrast, industrial city was inactive, shaped by and dependent to factors exogenous to the city. Since 1960s a new form of space accompanied by a new kind of urbanism has been created at a global scale. This new space relies on modern transport and 
telecommunication technologies such as motorways and airplanes and creation and destruction of suburbs, peripheries and historic centers over time (KATZNELSON, 1993: 96). The built environment is determined by economic forces, or mode of production ${ }^{1}$ and corresponding rhythms of capital accumulation operated at the large scale (KATZNELSON, 1994: 103). Hence, the space is not simply a human-built environment, but it is also a force of production and an object of consumption. In the words of Harvey (1999: 234235), "all aspects of production and use of the built environment are brought within the orbit of the circulation of capital". The built environment is necessary for the accelerated development of the capitalism. "At times, however, it may also become an impediment because a built-environment is fixed; it is a vast humanly created resource system, comprising use values embedded in the physical landscape, which can be utilized for production, exchange and consumption" (KATZNELSON, 1993: 111). From this perspective, the built environment does not only allow the acceleration of the capital, offer places to invest and reproduce labor force, but also it provides the capital with a spatial fix to both deal with crisis of cycles very common in the capitalism and issues of surplus and underinvestment (KATZNELSON, 1993: 110). The rent functions as a rationing device to allocate the land among various uses in this process. Hence, it can occupy a strategic role in coordination of the capitalist mode of production through the circulation of capital in a search for profit. As the capital circulates through the land uses, it fashion the spatial organization that inevitably creates contradictions (HARVEY, 1999: 332-336). Within this context, cities can be viewed as a creature of the spatial concentration of social surplus product that the mode of economic integration has to produce and concentrate. It is the locus of relations between the social surplus and the spatial organization of the society (HARVEY, 1973: 203-216).

Besides being an element of the mode of production in a capitalist system, the space is an object of political struggle and extensively used as a control instrument by the state (KATZNELSON, 1993: 98) through its reorganization and modification at different scales (POGGI, 1978: 1-2; ŞENGÜL, 2001: 147). For that, the spatial planning has been utilized to control

1 The capitalist mode of production is defined by distinctive forces of productions (physical means including land, tehnology and human made built environment and labor power) and a specific set of relations of production (economic power and social classes) operates to modify the space according to its own needs. For details see Peter Dicken and Peter Lloyd, Location in Space: Theoritical Perspectives in Economic Geography, Third Edition, New York, Harper Collins Publishers, Inc., 1999: 340-346. 
the social order by manipulating the space. For example, Barron Haussmann undertook a massive reconstruction of Paris for Louis Napoleon in $19^{\text {th }}$ Century. He removed all slums, where workers concentrated, along with isolated narrow streets that regularly used for and facilitated protests against the established regime. After removal, wide avenues were built in the opened areas to quicken and to efficiently serve to the conduct of commerce and maneuvers of troops that tried to put down the urban disorder (FISHMAN, 1998: 28). The interrelations between the social classes and the spatial aspects of the urbanization have extensively analyzed by Castells (1977) and Harvey (1973). Both authors view urbanization as a process that produces spatial structures and forms, supporting recreation of social relations for the capital reproduction. Hence, urban arenas function to recreate power relations, shape urban meanings and spaces.

The spatial scale of the state and its reconfiguration has closely followed the historical development of the political system and social relations, beginning with the feudal system, the nation-state and the supra-national state as exemplified by the EU (ŞENGÜL, 2001: 137). Feudal sovereigns imposed their rules in small feudal domains that were disorderly organized agglomerations of decentralized authority with incomplete power and limited coerciveness. As the commercial capitalism expanded in the early modern era, the power, space, and agency also began to change (POGGI, 1978: 1-2). Hence, the emergence of supra-national political entities such as the EU is, in one sense, the current outcome of the long historical spatial evolution of the political power, beginning with the patched space of the feudal polity to integrated space of the nation state and finally to the most recent formation of supra-national polities that attempt to recast the space in line with the needs of highly mobile capital (ŞENGÜL, 2001: 147-148). Indeed, these stages are noticeable in terms of their strong correlations with different modes of capital accumulation. The current flexible production system led by hypermobile capital requires removal of the previous nation-state's political boundaries in order to combine different place-embedded socioeconomic forms in a most profitable way. On the other hand, as Castells and Hall (1997: 478) point out, ITT allowed companies to go beyond these spatio-temporal constraints through its capabilities that both help the digital transmission of data and information across the globe and development of new forms of organizations in management and production. Within this context, considering that labor is relatively less mobile compared to the capital, the ESDP is an attempt to eliminate spatio-temporal constraints that prevent companies to stretch out production process and take advantages of a common European market along with relatively lower labor costs in specific regions. Indeed, the European 
geography of the production has undergone significant changes in recent years. The most noticeable of these is the shift of the auto assembling activities from developed regions of the EU to the periphery regions in new members. As Harvey (1999:237-238) points out, the capitalist search for higher profits across the space is accompanied by constant creation of particular places and destruction of some others, hence ultimately leading to new spatial barriers and spatial imbalances in economic development. One solution to the problem of spatial barriers resulted by the internal logic of the capital accumulation in the territory is a development of an urban hierarchy that links and in one sense homogenizes the economic activities over the space (ŞENGÜL, 2001: 147).

The Marxist political economic perspective views the class struggle and the accumulation of the capital as a vital part of the economic underpinning of the social order in the urban scene and basic processes of the capitalist expansion (FLANAGAN, 1993: 88). The reorganization of the urban space through programs such as urban renewal, mortgages and suburbanization in North America are associated with capital accumulation and class struggle. For example mortgages were used to divide the urban working class into those who own homes and those who does not. Furthermore, in contrast to workers who consume the urban space through socialization, leisure, and living, the land owners and capitalist use the urban space to gain rents, dividends, and interests (SAWERS, 1984: 9-10; HARVEY, 1985: 42-43).

The class struggle associated with the flexible production and relevant internationalization of the economic activities has significantly transformed into a new stage. As a result of the increasing mobility of the capital, jobs losses in inner cities in US and other developed countries can be contributed to the internationalization or global redivision of the labor markets (FLANAGAN, 1993: 91). By relocation the capitalists can reduce the power of the labor, as they move more freely across space and thus force local communities to compete with each other for investment. The labor becomes powerless to struggle for higher wages and better working conditions by new models of production process and the treats that the company may move to another place. Hence, the capital can discipline and assume the control of the labor in a particular place (HARVEY, 1989: 156-157; ŞENGÜL, 2001: 154; DICKEN/LLOYD, 1999:391-396). The current technologies and mobility of the capital give companies the ability to develop spatial strategies simultaneously utilized to reduce the power of the labor against the capital and to foster conflict between labors in different places.

In sum, a spatial approach provides new insights in many contexts and thus can help us to better understand spatial factors affecting the EU's integration and social cohesion for several reasons: 
- location may determine conditions, context, and causes of activities;

- spatial proximity indicates similarity of conditions, context, and causes;

- spatial proximity may also act as a surrogate for interaction and information fields;

- spatial structures can be considered as the diagnostic of a process.

The economic literature has long pointed out the role of proximity and clustering as the driving force behind the territorial success. More recent theoretical development on concepts of increasing returns and agglomerations gives more justification for the inclusion of space in any theory of economic development (CAMAGNI, 2003: 1-2) and thus related policies. In short, the space does not only provide companies with advantages of lower production and distribution costs through proximity and positive externalities, it also offers informal social, cultural, institutional, and political benefits that ultimately foster economic relations. Space can also be utilized as an integral part of the corporate strategies to reduce the labor power and thus increase profits.

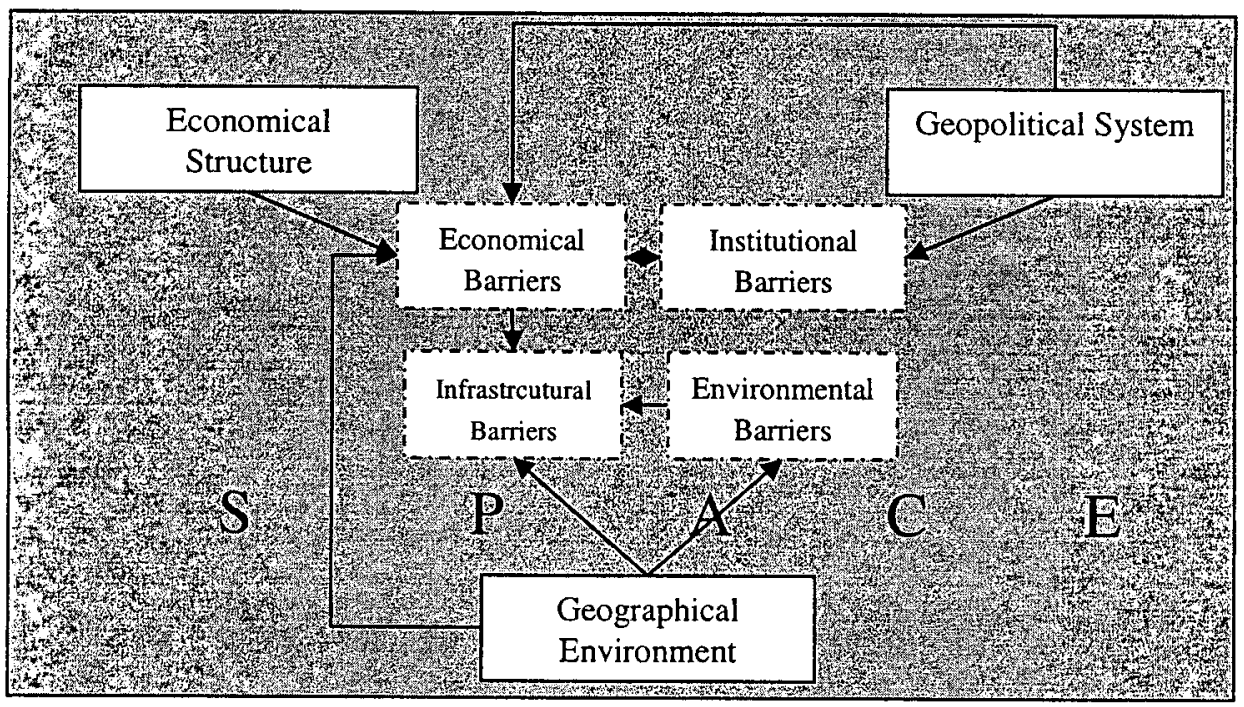

Figure 2. Spatially-materialized socioeconomic features in the geography

Source: Redrawn from Komornicki, 2002, p.5.

Figure 2 shows the spatial framework utilized in this study. Economical, geopolitical and geographic characteristics of states forming the EU create several internal and external barriers ranging from economical, institutional, 
infrastructural, environmental and even psychological to further cohesion. Whether it is an institution or economic activity, every human activity has to be organized in space. Hence, each social, economical, political and institutional barrier has a spatial dimension that needs reconfiguration in the face of new changes brought by the EU's integration. On the other hand, the location of specific activities over the space creates a need for interaction of similar and different activities and thus infrastructure, communication and transport networks.

This discussion reveals that the economical, political and social integration has to be considered together with their spatial dimension. Spatial integration may be defined as the reduction of distance between regions or geographical areas with respect to time, monetary costs and psychological distances. Spatial integration may be achieved through establishment of dens transport and communication networks that increase fast movements of people, delivery of goods and dissemination of information. In other words, spatial integration means 'to make borders as penetrable and 'spiritualised' as possible. It also implies creating transnational cooperation networks between cities, regions and the other actors of spatial development" (ESPON, 2002, 49). Thus, infrastructure such as transportation and ITT can play a major role in overcoming physical distance as well as spatially-materialized socioeconomic constraints by allowing institutions and individuals to interact more easily and even enabling them to replace physical movement with electronic transmission.

\section{EU and Turkey's Policies of Spatial Development and ITT Compared}

The EU's enlargement process accompanied by economic and political integration had dramatic impacts on the European spatial development policies and will continue to challenge planners throughout Europe. Aware of this fact, spatial planning activities at the European, transnational and cross-border levels have gained a momentum in recent years, while raising questions about the role and authority of the Union with respect to planning (METCALFE, 2001: 139).

The EU already has a large territory covering 25 states. This territory will perhaps increase further in the future with new members envisioned to join to the EU short after 2004. With these new members, 490 million people will be living on a $4,300,000 \mathrm{~km}^{2}$ (ESPON, 2004). Three factors seem to influence long-term spatial development trends in the EU: (1) "the progressive economic integration and related increase in co-operation between the Member States", (2) "the growing importance of local and regional communities and their role in 
spatial development", and (3) "the anticipated enlargement of the EU and the development of closer relations with its neighbors" (CSD, 1999: 7).

An extensive debate exists on the final destination of European spatial integration (for example, see CAPORASO, 1996 and WAEVER, 1997) and mostly seems to be state-centric (ZIELONKA, 2001:507). Zielonka (2001:507) argues that contrary to a Westphalian (federal) state with a central government in charge of a well-defined geography and clear-cut borders, the the EU is destined to fail in accomplishing an overlap between its functional and geographic borders, as long as the huge degree of divergence that result from further enlargement remain an issue. While this argument carries some merits, it also seems to ignore impacts of the new ITT on spatial organization of human activities and the nature of capital accumulation that inevitably results in uneven spatial development. Indeed, the EU has just recently begun to develop spatial development and ITT policies to overcome these spatial constraints. But, their success remains to be seen and perhaps at large extend will require more radical measures than those adopted by the EU.

\subsection{EU's Spatial Development and ITT Policies: toward Spatial Integration}

An EU's common approach to spatial policy has emerged as a result of a concerted attempt to impose some vision and coordination across a diverse set of policies, regulations and other instruments applied to economic and social objectives of the union. In the past, the EU has overlooked spatial impacts of many of these policies and programs during the implementation and evaluation face (RICHARDSON/JENSEN, 1994: 503). However, the EU's concern with spatial development has increased in the last two decades, since many policies become concrete on the space. Thus, there was a need for protecting the space with respect to the EU's common principles (GEDIKLI, 2002: 3). The EU's spatial planning efforts are quite old and go back to 1945 (METCALFE, 2001: 139) (see METCALFE, 2001; ÜNSAL, 2001; ORAL/ECEMIŞ, 2001; KESKINOK, 2001). Spatial planning may be defined as the methods that public sector utilizes to influence the future distribution of activities in the space. Thus, the purpose of spatial planning is to create a more rational territorial organization of land uses and linkages that connect these land uses in order to balance economic development with a desire of protected environment, and to achieve specific social and economic objectives. Spatial planning has a wide range of measures to coordinate spatial impacts of different economic sectors and to succeed in distribution of economic activities between regions that otherwise may develop differently under market forces (ESPON, 2004). 
The efforts of DGXVI and the Infra-National Committee of Spatial Development (CSD) during 1990s led the EU to progress a series of initiatives on spatial cooperation in Europe. The major developments in the areas of the European spatial policies have been the explorations of European spatial trends and concepts in Europe 2000 (CEC, 1991) and Europe 2000+ (CEC, 1994) as well as the Compendium of studies analyzing the spatial planning systems and policies in the member states (CEC, 1997). These documents explicitly provide clues "of an intertextual connection of plans and visions for the EU, which are all part of the discoursive construction of a new spatial policy and planning field" (Richardson and Jensen, 2000: 504).

This paper will only focus on the activities of the European Conference of Ministers Responsible for Regional Planning (CEMAT) ${ }^{2}$ and the European Commission's European Spatial Development Perspective (ESDP) ${ }^{3}$ that so far covers most objectives and content of the EU's spatial development efforts. The paper will first summarize objectives in the EU's spatial development efforts in light of the framework provided above and then go on to critically discuss their practical implications for the integration.

The spatial planning activities of European Conference of Ministers Responsible for Regional Planning (CEMAT) began in 1970 in Bon. Since then, the EU has adopted various fundamental documents that are specifically related to spatial development issues. Between 1983 and 2002, the CEMAT carried out the following activities:

- The European Regional/ Spatial Planning Charter, which was adopted in 1983 at the 6th Session of CEMAT in Torremolinos. This charter was later incorporated into Recommendations (84) 2 of the Committee of Ministers to member states on the European Regional/ Spatial Planning Charter

- The European Regional Planning Strategy presented at the 8th session of CEMAT in Lausanne in 1988,

2 CEMAT (European Conference of Ministers Responsible for Regional Planning), The Guiding Principles for Sustainable Spatial Development of the European Continent, Council of Europe, Hanover 7-8 September 2000.

3 CSD (Commission on Spatial Development), European Spatial Development Perspective - Towards Balanced and Sustainable Development of the Territory of the $E U$, the Informal Meeting of Ministers Responsible for Spatial Planning of the Member States of the European Union, European Commission, Office for Official Publications of the European Communities, Luxembourg, Potsdam May 10/11 1999. 
- The Guiding Principles for Sustainable Spatial Development of the European Continent, adopted at 12th Session of the CEMAT held in Hanover in 2000 and incorporated into Recommendations (2002) 1 by the Committee of Ministers to Member States on the Guiding Principles for Sustainable Spatial Development of the European Continent.

The ESDP definitely represents the latest development in a decade-long effort to shape the EU's spatial planning policy. The process has been a durable commitment of large amounts of human resources that has only produced a non-binding document (JENSEN et al., 1996: 16). While this document can be viewed as a tentative step toward the development of the EU' spatial planning policy, as Richardson and Jensen (2000: 503) argue, the eventual success of the ESDP will much be dependent on its effective implementation across regions and member states. On the other hand, the ESDP remains at large extent an intergovernmental rather than a European document (FALUDI, 2001).

The European Spatial Development Perspective (ESDP) was a French and Dutch collaborative initiative to add a spatial dimension to the EU's regional policy. The ESDP has gradually evolved from informal meetings of the EU's member states and their own spatial planning experiences. Therefore, it bears traditions and aspirations of the member states, especially those of the Netherlands, the Federal Republic of Germany and United Kingdom (EC, 1997; FALUDI, 2001). At Postdam in Germany in May 1999, the planning ministers of the EU's member states adopted the final version of the ESDP. This success can be contributed to efforts of both Member States and the European commission that has been interacting and dealing with spatial issues of the union over the past ten years (FALUDI, 2001). Many similar issues in the member states and attempts to address them have directly or indirectly contributed to the development of a European-wide spatial perspective. This perspective somehow views space as a common basis on which a diverse set of policies with territorial impacts have to build and as an instrument to coordinate and harmonize all development efforts. After all once modified, this space can gradually become an obstacle for further development. Therefore, the planned common space would need to meet to the future challenges of the neo-liberal economic order.

Both the ESDP and the Hanover Document, the Guiding Principles for Sustainable Spatial Development of the European Continent (GPFSSDEC), rely on the same ideological world view and assumptions, and therefore present similar spatial development objectives for the EU. This is not an accident, however, considering that the principles of the ESDP nicely suit inside the CEMAT's Document (CSD, 1999). The only distinctive characteristic of the 
GPFSSDEC is that it attempts to address spatial development issues and policies of the entire Europe through some broad guidelines (CEMAT, 2000). Furthermore, the contents of the ESDP and GPFSSDEC seem to be worded differently (see Appendix A) at first sight, but a closer inspection reveals that they mean the same things. Both documents can best be described as a neoliberal-conservative political outward perspective in terms of spatial organization they sought out, perhaps reflecting to elite circle actively involved in their preparation. The ESDP was a product of a closed process accessible only by a national spatial planning elite (CSD, 1999), whereas the Hanover document was produced by a committee of the ministers representing member states and thus at large extent dominated by their political views (CEMAT, 2000). Hence, in both documents, a tension between the conservative world view that does not seek for radical changes in the reorganization of the European space and the neo-liberal view obsessed with strengthening competitiveness of the European economic space gets an immediate attention. This tension between preservation of the European space with all cultural, ecological and economic treats as they exist and its reconfiguration for adjustment to the new global spatial economic realities frequently arise throughout both documents, even in sections discussing policy objectives of protecting ecological and cultural diversity in the European regions. The ESDP perceives "Natural and Cultural Heritage as a Development Asset" in discussing policy objectives of the "Wise Management of the Natural and Cultural Heritage". It states that "the natural and cultural heritage are economic factors which are becoming increasingly important for regional development" (CSD, 1999: 30). Similarly, the GPFSSDEC, on the one hand, attempts to preserve the cultural and ecological diversity of the Europe through some guiding principles; on the other hand, it views them as assets to increase attractiveness of European regions for investors and thus to foster economic development (CEMAT, 2000: 11-12).

The assumptions both documents rely on spring from the well-known neo-liberal theory. In summary, it says that the special income and development gaps tends to decline in the long term, as the capital searches for higher profits and labor for higher wages through movement, ultimately leading to a spatial equilibrium in which regional development difference are minimized. This argument, however, runs into some problems as the precedent discussion showed. First, capital is relatively more mobile compared to the labor for sociopsychological and political reasons. Cultural and language differences also are likely to remain a barrier to the free movement of the labor. Second, the envisioned European space in the both documents seems to reinforce the historical patterns of the regional dominance further. These aspects are 
discussed below. Third, the logic of the capitalist accumulation and accompanying corporate spatial strategy pursued to reduce the labor power ultimately require spatial development gaps. In a sense, the capitalist mode of production and its current version of the flexible production system require and lead to spatial development differentiations to exist. These factors operate together to create class conflict and spatial injustices. In summary, the major concern in the both documents is the strengthening of the EU's economic power by reorganization of space in a way assumed to contribute to social and economic cohesion and thus the European integration. There is also a concern to enhance the position of the EU's regions in world markets that have increasingly become more competitive.

The perception of the spatial planning throughout the ESDP and Hanover Document bears also a conservative ideological overtone. This is perhaps expressed best in frequent statements related to anti-immigration, preservation of existing urban hierarchy that has provided the European core regions with disproportional advantages over the past, concern on protection of transfrontier borders, establishments of some second class "gateway cities in peripheral regions", and economic-centric view of the natural conservation. If any thing these spatial policy objectives may do in the case of their implementation, it is going to reinforce existing West-oriented spatial patterns established during hay days of nation-states. There is almost no discussion in these documents for a European-wide vision of spatial planning that relies upon utopian concepts and radical transformation of the space. Hence, most of the objectives explicitly remain silent on ethical issues such as relations of the territorial capital accumulation with spatial justice, equality and class conflict. The present spatial economic outcomes that are also likely to reinforce strengths of the already well developed regions in the future can partially be contributed to spatially-biased previous technological distribution. The establishments of the second class "gateway cities" may perhaps strength urban relations of these centers with the urban hierarchical system within Europe. But, it may also weaken their relations with their hinterlands and internal regions.

Indeed, the emerging new international division of the labor is characterized by capital- technology/ information- intensive advanced core regions and labor -intensive industrial peripheries made up by less developed regions. In this new world, economic disparities increase not only between the dominant and exploited classes, but also between genders and between different ethnic groups within a country or region (DUPUY, 1998). Uneven development causes population movements between the advanced zones and raw -resource zone of production at regional and global scale, depressing wages, weakening the power of workers, unionization, and regulations. Therefore, places and 
networks of economic production are interdependent poles in the new spatial mosaic of global production. Within this context, globalization and corporations do not universally influence all places equally, but rather systematically search for the synthesis of cultural diversity corresponding to differentiated regional innovation logics and capabilities (GORDON, 1994: 46).

The EU's reliance on already known planning concepts such as "polycentric spatial development", "partnership between urban and rural areas", "partnership with private sector in spatial planning", and "citizen participation" is not going to make a significant change in well established regional differences. Considering the ESDP is only a perspective for the EU's spatial activities, and like Hanover Document does not legally bind any member state, this argument bears merits.

Several major common policy objectives can easily be extracted from the two documents. Table 1 shows these common spatial policy objectives. As Table 1 shows the space is given a key role in harmonization of diverse socioeconomic policies and achieving European integration. Besides, the ESDP determines several programs that form the basis for the EU's actions with spatial development implications. These are Community Competition Policy, Trans-European Network (TEN), Structural Funds, Common Agricultural Policy (CAP), Environmental Policy, Research, Technology and Development (RTD), and Loan Activities of the European Investment Bank (CSD, 1999: 13).

- Space as a new dimension in EU's policies plays an important role in social and economic integration, conservation and management of natural resources and cultural heritage, and more balanced competitiveness of the European territory

- Strengthening of European space competitiveness

- Promoting territorial cohesion through a more balanced social and economic development of regions and improved competitiveness

- Development of a polycentric European settlement structure and Eurocorridors

- Promoting more balance accessibility and developing access to information and knowledge

- Principles of subsidiarity and reciprocity in preservation of unity in diversity and enhancement of democracy 
- Sustainable and regionally balanced spatial development to preserve ecological and cultural diversity

- Voluntary rural, urban, regional and transnational cooperation

- Close cooperation between spatial planning and sectoral policies

- Intercontinental and inter-trading economic blocks relationships as strategic elements for European spatial development policy

- Euro region or exchange corridors as appropriate scale for action

- Enhancing regional identity and diversity that act as powerful factors in social cohesion and regional development

Source: Extracted from CEMAT, 2000 and CSD, 1999.

The development of a balanced polycentric city system and new urbanrural relationship are the core concept in the ESDP (CSD, 1999) and GPFSSDEC (CEMAT, 2000), making up the basis on which other policies with territorial impacts rely to successfully create an ultimate competitive European space. The concept of polycentric spatial development is dynamic in that it regards cities not only as supply centers and settlement structures, but also driving forces behind the development and functional networks that activate regional resources (ESPON, 2002: 3). The strengthening of the access through establishment of a pan-European transport infrastructure connecting all cities and ITT policies that also support improvement of the European work force complete the objective of polycentric spatial development. On the other hand, Cappelin (1991: 237) argues that the dynamics of globalization tends to reduce the relative importance of the urban relations with their hinterlands or regions by enabling cities to act as independent economic agents, leading to increasing economic disparities between the urban poles and respective hinterlands.

The city system the EU attempt to realize, however, is not new and can be traced back to Central Place Theory (CHRISTALLER, 1933). Similarly, the ESDP promotes development of metropolitan regions at European level as global integration zones, enforces a polycentric system of metropolitan regions, city clusters and urban networks at transnational level, and encourages system of cities including the corresponding rural areas and towns at national level (ESPON, 2002).

To realize a balanced polycentric spatial structure, the ESDP (CSD, 1999) provides several objectives: 
- By using transnational spatial development strategies, the strengthening of several larger zones including, their peripheries, that enable the EU to integrate with world markets and to function as the producers of high-quality global services,

- Development of a more balanced polycentric system formed by metropolitan regions, city clusters and city networks and linked through a close cooperation between the Trans-European Networks (TENs) and structural policies.

- The polycentric city system also necessitates securing access to infrastructure and knowledge through improvement of the links between international, national, regional, and local transportation networks.

- Promoting integrated spatial development strategies for city clusters together with their rural areas in member states within the framework of transnational and cross-border co-operation,

- Enhancing cooperation on specific subjects through spatial development policies that involves in cross-border and transnational networks.

- Promoting cooperation at regional, cross-border and transnational level; with towns and cities in the countries of Northern, Central and Eastern Europe and the Mediterranean region; Enhancing North-South links in Central and Eastern Europe and West-East links in Northern Europe (TREANOR, 2004).

The ESDP (CSD, 1999) clearly distinguishes metropolitans in the "Pentagon" defined by a core area including such cities as London, Paris Milan, Munich, and Hamburg, from those in peripheral regions of less developed Europe. It proposes the establishment of the several pseudo- core metropolitan regions in peripheral areas in order for the development of a balanced polycentric urban structure throughout Europe. These cores are assumed to function as growth pools attracting economic activities and thus reducing gaps in economic development between the core and peripheral regions. The GPFSSDEC (CEMAT, 2000) similarly advocates the development of a polycentric urban settlement structure and pseudo-peripheral cores, though with a different strategy. It proposes establishment of "gateway cities in the European periphery", high-order cities with links to the network of other established cities. Accordingly, the network of gateway cities will assume the role of reducing socioeconomic gaps that the presently divides the European continent into a core and periphery. The development of several growth pools across the continent is expected to help in preventing some isolated urban or 
regional centers to emerge, attracting most of the investment, causing to serious environmental and socioeconomic problems, and creating tensions and destabilizing democracy within EU.

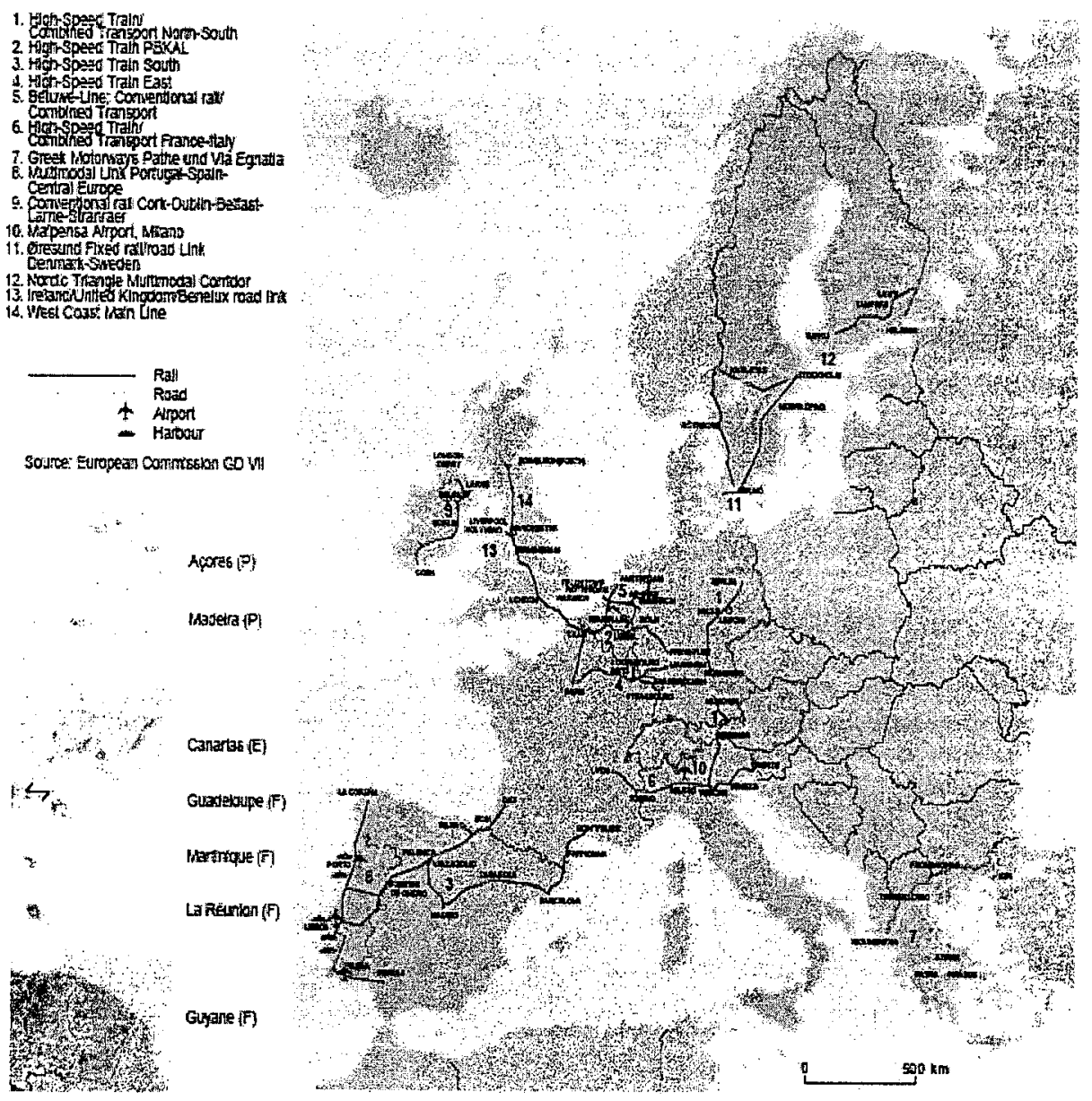

Figure 3. The balanced polycentric spatial development of urban structure shown by $A$ and the map of 14 priority projects of Trans-European Transport Network shown by $B$ Source: $C S D, 1999$, p. 15,26

The improvement of transport, information and telecommunication infrastructure is a vital component of the balanced polycentric spatial development policy. After all, it links regions and settlement structures of 
different scales together to support the flows of goods, services, people and information throughout the system (CSD, 1999; CEMAT, 2000) Naturally, these two, land use and transport-ITT infrastructure, have to be considered together, as each affect the other, or vice versa (BOARNET/MEDDA, 2003). Thus, there is a good reason why the EU emphasizes so much on transport and ITT policies in the both documents, as the following short literature review will show.

The EU has increased financial resources dedicated to regional RTD (Research, Technology and Development) from 2 billons EUR in 1989-1993 to 5 billion EUR during the period between 1994 and 1999. Yet, the technology disparities across European space continued to remain an obstacle when compared to cohesion gap. Between 1994 and 1999, while technology gap measured as GERD/ GDP was about 5:1, the cohesion gap between the poorest and richest member state was less than 2:1 (GUTH, 2000:1-2).

The improvements in transport and ITT have enabled economic activities and other forms of the human organization to find new ways of overcoming spatial constraints (BOZKURT, 2000: 94-95). First, as these new technologies have rapidly improved, there has been a parallel dramatic decline in spatial interaction costs that have so long put constraints on the spatial organization of production process and location decisions. Today, these technologies provide firms with many alternatives for the spatial organization, ranging from separation and relocation of activities in different geographic settings, establishments of networking firms, to virtual enterprises formed by a leading firm that coordinate and control production and marketing and some other firms with different functions (MARIN, 2004: 253; MARIN, 2004: 2003: 736). Secondly, because the current global economy relies on information technologies, increase in the productivity results from processing, management and application of information to production and distribution of goods and services rather than increase in conventional production factors such as labor, capital and land (BORJA/CASTELLS, 1997: 7). Thus, ITT enabled firms to reduce business costs, while increasing productivity at the same time. The collection, storage and process of the information is not also solely unique to information-intensive production processes, it has spread across all economic activities in our time (MOSS, 1999). Hence, the production and strategic process of the information plays a major role in productivity and competitiveness of firms functioning in the contemporary global world markets. This in return led to transport and ITT along with human capital to increasingly become more important in regional and urban economic development policies (BORJA/CASTELLS, 1997: 7-8). Information and telecommunication technologies such as Internet have also reduced previously impermanent 
geopolitical borders of the nation-states to insignificance, while increasing the volume and speed of interactions at local and global levels. These changes brought cities and regional governments to forefront as unit of economic activities and active agents in regional economic development policies.

One of the well-known arguments in the economic geography is that the networks that link activities of various firms in different sectors creates innovation and enhances productivity. Rapid and dramatic changes in world markets and decreases in innovation periods have given a rise to the significance of collective efforts of firms in different sectors, research and social institutions, making them the real engine behind current technological improvements and economic development (LAPPLE, 2001; CAMAGNI, 1991). So, the effective utilization of ITT by most economic activities is still dependent on specific places where these technologies and institutions adequately present (GALLIANAO/ROUX, 2001: 2).

The most important objective of the European integration was and still is economic and social cohesion. The Single Act in 1986 further defined this objective and delegated political responsibility for an enhanced economic and social cohesion to the EU. This objective was going to be realized through reduction of income and development gaps between the regions, since the European history has repeatedly shown that large income disparities coincided with political conflict and radicalism. The Single Act also allowed the Union to formulate some policy tools that would ensure economic and social coherence: (1) coordination of policies in member states, (2) the Single Market Program, (3) the European Structural Funds, (4) the European Investment Bank (EDB) and (5) other financial instruments (GUTH, 2000: 2). Spatial development and ITT policies are more recent attempts to bring the spatial dimension as a coordinating and harmonizing factor to implementation of all other policies. The spatial policies are aimed at promoting social cohesion and further integration through a more balanced territorial development characterized by a polycentric settlement structure that links cities, regions, and corresponding rural hinterlands across the EU, regardless of geopolitical barriers, to form an active network. Investment in transport and ITT infrastructure that connects the entire European space and performs similar functions as blood vessels in human body is assumed to increase the access of settlements to markets and knowledge, thereby creating both an environment conducive to innovation and competitive economic space attractive to foreign investment.

According to the GPFSSDEC, a coherent strategy "for integrated and regionally balanced development of our continent (Europe)" should be based on principles of "subsidiarity" and "reciprocity", "strengthens competitiveness" in a globalizing world market, "cooperation and solidarity" among local and 
regional authorities across borders. Hence, the implementation of Guiding Principles requires a close cooperation between spatial planning and sectoral policies that can affect spatial structure through their measures. This is expected to contribute to the democratic stability of Europe. GPFSSDEC also calls for cooperation of states on Black See and Euro-Mediterranean regions in their future spatial development policies in light of Guiding Principles. The GPFSSDEC is well aware of the role transport and telecommunication infrastructure can play in spatial integration by emphasizing "the speedy development and implementation of pan-European Transport Network (especially the 10 Pan-European Transport Corridors)" that will increase the accessibility of large areas across the whole continent (CEMAT, 2000).

The EU's spatial development and ITT policies are likely to reinforce the historically dominant roles of regions, especially the Pentagon made up by urbanized areas of information-intensive economy, in the future. The European urban hierarchical structure may increasingly integrate

\subsection{Turkish Spatial Development and ITT Policies}

Unlike the EU, Turkey has not so far developed a national spatial development and ITT policies, even though State Planning Agency (DPT) has over time adopted some relevant policy guidelines. Furthermore, presently a diverse set of laws give responsibility and authority to several ministers, municipalities, and metropolitan municipalities to implement various policies with territorial impacts, while ignoring functional and spatial relationships that arise among different settlement structures across the whole country. Instead, it seems that the major efforts, albeit not directly relevant as in the EU's policies, in the spatial development in Turkey have mainly been concentrated on the three basic issues: urban conglomerations of various small and large cities that attract rural migrants and thus create socioeconomic problems, regional socioeconomic gaps that divide the country into a rich core and huge periphery, and socioeconomic development of rural areas and prevention of rural migration. To address the first issue, Turkey has adopted municipal and metropolitan municipality laws to determine administrative boundaries, responsibility, authority and political statues of metropolitan and encompassed smaller district municipalities. The basic purpose in these laws is to reduce conflict and address coordination problems through clearly defined responsibilities and authority of each municipal body in socioeconomic and political areas, including land use and transportation planning, taxing, legal basis for creation of metropolitan statue, administrative and political structure. 
Studies on regional development in Turkey demonstrate a large income gap between regions. Indeed, between 1983 and 1998, the average per capita GNP index ranged from 156 in Marmara to 41 in Eastern Anatolian Region (DPT, 2000: 70). Historical factors, national policies, market size and distribution of the basic infrastructure have all contributed to geographical distribution of industry and corresponding spatial income gaps in Turkey. Today, regions of Marmara and Aegean as well as some cities in Central Anatolia and Mediterranean regions house most of the industrial production (see figure 4). This regional development differences clearly indicates large income and indusial production gaps, leading to a rich core area centered in the western and a poor periphery covering especially eastern and northern parts of the country (TEKELİ, 1984; ERKUT/BAYPINAR, 2003). The persistence of this spatial dualism between the West and East has long characterized the spatial development and continues to rise (GEZICI/HEWINGS, 2003: 2). The progress report of the Council of Europe in 1999 directs attentions to serious regional income gaps in Turkey and the country's relatively low per capita GNP in comparison to that of the union (AKTT, 1999: 84-85). The commission's report in 2000 (AKTT, 2000: 72-73) points to the need for development of an effective regional policy and accompanying institutional changes aimed at reduction of regional income disparities, as Turkey prepares for membership. The report proposes an immediate attention to be given to the following areas:

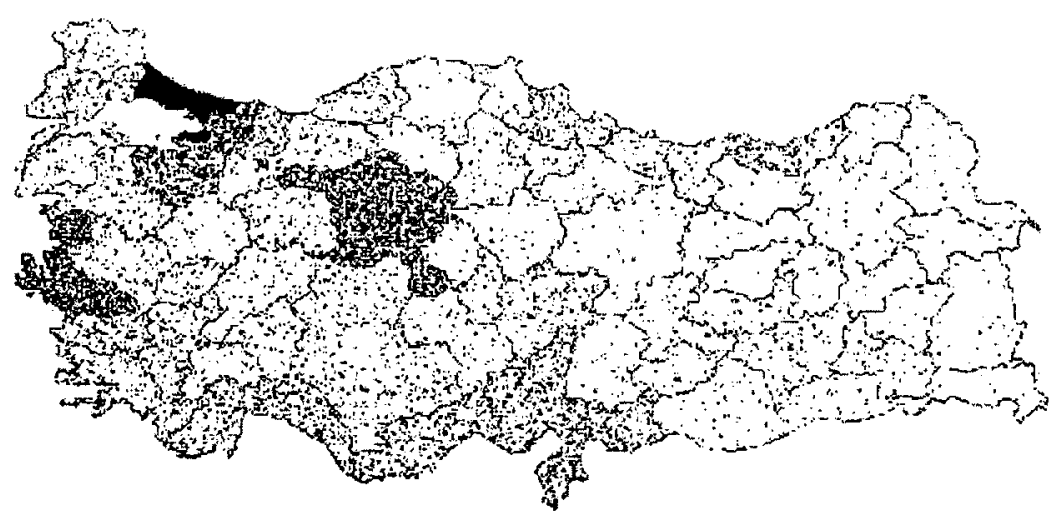

Figure 4. The geographical distribution of industrial firms in Turkey

Source: Erkut and Baypinar, 2003, p. 17.

- The present regional policies should be implemented with all structural and legal changes required by the EU; 
- There is need for development of NUTS, regional statistical areas, where structural regional policies carried out in line with the union rules ${ }^{4}$;

- Analysis of public investment does not indicate an effort for improvement of the poor regions;

- Most regional and rural development projects of the State Central Planning Agency (SCPA)'s have not been implemented;

- The SCPA should be organized at regional and national level.

To address the regional development and income disparities, the state has over time developed various policies aimed at improvement of socioeconomic conditions of the poor regions through place-specific large state projects and a set of fiscal and economic incentives for the companies locating in the cities within geographic boundaries of the poor regions. Thus, the second group policies may broadly be classified into two subgroups. The first group policies involve in publicly financed-large state projects as in Southeastern Anatolian Project (GAP) or Eastern Anatolian Project (DAP). These projects utilize indigenous regional resources to improve socioeconomic conditions of the citizens. Furthermore, these policies are much broader in their contents, for they attempt to bring sectoral, social, land use and transportation policies as well as institutions and local citizen to activate regional resources (MARIN/ALTINTAŞ, 2003) The policies making up the second subgroup are relatively narrower in their scope and urban-specific in that they define regions based on GNP and similar socioeconomic indicators as developing, primary, and secondary development areas where firms were given some fiscal and economic incentives to operate (see Figure 5 for provinces that are defined as primary areas in development). As Erkut et al (2001: 117) point out, there have been several attempts of Turkish regional development initiative in Turkey since 1950, but these were more formalized and carried out after 1963 through Five Year-National Development Plans and activities of various ministers.

4 Turkey developed the Classification of Statistical Regional Unites (CSRU) on 22 September 2002 to meet an important requirement of the Union. The CSRU is expected to help in analysis of regional socioeconomic conditions, development of effective regional policies, and comparisons with statistics of the EU (for more details see the official web side of State Central Planning Agency (DPT) at http://www.dpt.gov.tr/bgyu/). 


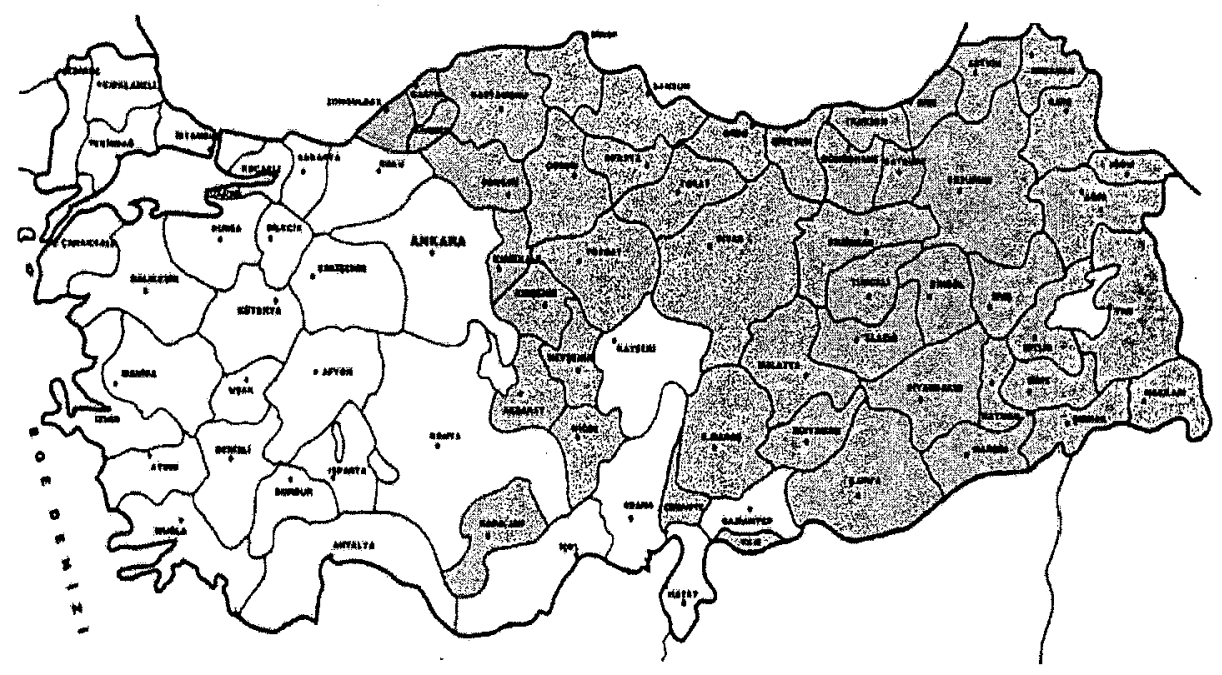

Figure 5. Provinces defined as Primary areas in development Source: DPT, 2004.

Finally, the third group policies have historically evolved from the needs of the new republic to improve rural areas through their socioeconomic transformation (GERAY, 1999: 12). Since the foundation of the Republic of Turkey, urbanization of the large rural areas to build a Western type industrialized society with modern values was a major concern among the polito-bureaucratic-army elite (GEDIKLI, 2002: 11). Intellectuals, political parties and state officers have developed concepts and utopian plans to address various problems associated with barriers confronting the rural development. Cities were viewed as active agents in the transformation of the society through their role in dissemination of republican ideology among the largest segment of citizens. Therefore, the state felt an urgent need to build small towns across large rural parts of the country in order to rapidly transform the traditional society into a modern one. These plans simply failed due to ignorance of feasibility studies and spatial relations, and unfamiliarity with socioeconomic conditions in the rural areas. Today, projects such as village town, central village or agro-town still remain at large extent an ideal in many minds for rural development.

Turkey has lifted restrictions on its economy since 1980s through liberal policies of its trade regime, currency and movement of foreign capital in order to better integrate with world economy and the EU as well as to attract foreign investment. But, these changes have also affected spatial organization and spatial income disparities through the industrial growth and their location decisions (ERKUT/BAYPINAR, 2003: 1-3). 1980s also mark a change in 
economic policies of many nations including Turkey and the beginning of the financial dependency of cities around the world, as public spending and resources were cut back. The shortage of financial resources challenged many cities to find new ways of getting resources, mostly by policies that give some advantages to foreign and domestic firms for relocation. Thus, urban and regions have increasingly become entangled within network of the global economic relations as influential players in regional economic development, as the world economy and accompanying relations continues to relate and integrate human activities across the continents. As Tekeli (2001: 31-33) points out, perceived as a project of modernization in Turkey, urban and regional planning lost its significance in shaping post-1980 urban structures. Unlike cities in developed countries where overaccumulation of the surplus in the first circuit of the capital was channeled into the less profitable investment in urban infrastructure and services during 1960s, allowed the implementation of state welfare programs and allocation of resources for social consumption in those cities. By contrast, in Turkey, the economic system could not achieve this level of the capital accumulation and hence was unable to channel money into the built environment. Combined with the lack of state and municipalities resources to improve urban infrastructure and meet needs of increasing number of rural to urban migrants, these economic conditions have led to devastating impacts on Turkish cities (ŞENGÜL, 2001: 186-188). According to Ünsal (2001: 148), the vacuum created by the decline of urban and regional planning from the scene and unwillingness of the central governmental institutions such as Central Planning Agency to actively involve in planning after 1980s was filled out by citizen and other democratic institutions in Western Europe, whereas in Turkey by an informal structure made up by a rent-seeking coalition of interest groups, politicians and bureaucrats. Indeed, a recent report by a commission of the Turkish Grand National Assembly points to efforts of these informal coalitions in the development of squatter settlements in major metropolitan areas (ŞENER, 2003).

Current world economy has been reshaped by multinational economic blocks, advancement in technologies that enable rapid exchange of information, the liberalization of trade and capital flow (GEDIKLI, 2002: 5). To Unsal (2001: 148), accession to the EU and import of neo-liberal ideology may ultimately multiply problems associated with urban development in Turkey. It has been suggested that there is a need to create a strong image of our cities within urban system and build their competitive capabilities (KEYDER/ ÖNCÜ, 1994; quoted from ŞENGÜL, 2001: 158). Accordingly, the EU's accession processes requires changes at urban and regional levels, as it forces us to consider new models of economic developments that operate at regional urban network level and rely on marketable local resources for the global 
economy. This is a realistic scheme based on the fact that the present global economic world order continues to value and devalue every place in the network of exchanges. As Şengül (2001: 160-163) argues, this solution ignores the deep social meaning attached to the space and spatial justice that may arise within a country.

Spatial planning is an effort to locate and direct the distribution of various activities in space in a way that will harmonize the future socioeconomic development with natural and human-made environment. As exemplified by the ESDP, spatial planning has to be a means in all spatial development efforts. The State Central Planning Agency. (DPT) develops and carries out regional development policies in Turkey through plants for every five year. In 1980, DPT collected data for the first time to determine the spatial structure of Turkey. Using this data set, Mutlu (1988) conducted a serious study of the Turkish urban spatial hierarchy. ${ }^{5}$ On the other hand, the National Five Year Development Plans have generally been silent on the spatial issues, ignoring the close relations between socioeconomical policies and spatial development.

In this paper, the last National Five Year Development Plan, the $8^{\text {th }}$ State Five Year Development Plan, will be the focus in comparing Turkish spatial development and ITT policies to those of the EU. The plan points to the need to reduce regional income disparities prominent in the East and Southeastern Anatolian regions through activation of local resources and support of small business with financial resources. There is not a mention of the space, but an emphasis on the sustainable development among the principles, goals, and policies of the regional development. It also directs the attention to the need for classification of settlements areas to make the implementation, determination of goals, and coordination of economic decisions of regional development policies easier (DPT, 2000: 71-73).

Although they only remain as good concepts at large extent in the $8^{\text {th }}$ Plan, since all Five Year National Development Plans do not bind private enterprises but only those of public sector, there are some spatial development and ITT related objectives. Containing long-term development strategies that cover a 22-year period, the $8^{\text {th }}$ Plan mentions the following ITT and spatial development related objectives:

- transforming the country into an informational society;

5 For more details of Turkish spatial urblan hierarchy and its determinants see Servet Mutlu, The Spatian Urban Hierarchy in Turkey: its Structure and Some of its Determinants, Growth and Change, Volume 19, No 3, 1998, p. 53-74. 
- creating an export-oriented, technology-intensive, high value added, and local resource- based economy;

- sustainable development, regional integration, social and economical cohesion, improvement of the living standards, equal opportunity, cultural development and participation were defined as major criteria in all regional policy implementations,

- there is also a statement that points to the need for a more balanced distribution of resources and sectoral development in space as well as the need for harmonization of social and spatial development efforts.

Furthermore, the $8^{\text {th }}$ Plan notices the close association between competitive capacities of companies and the modern use of ITT. But, it also ignores the fact that ITT tend to concentrate in specific urban areas where they are utilized in the production of high-tech products. The issues of the ITT's impact on the spatio-socioeconomic development and its roles in building competitive capacities of cities are not adequately elaborated and addressed (DPT, 2000: 71-73). In other words, not only has there been a lack of the development of a spatial perspective with regard to regional economic growth and relations between spatial impacts and socioeconomic policies, but also a failure in understanding the fact that spatial development requires ITT and transportation infrastructure. Both spatial development and ITT investments have to be considered in conjunction with all other social and economic policies.

Moreover, the spatial development in Turkey has totally been left to individuals and capitalist economic dynamics since 1980, furthering the uneven spatial distribution of economic activities and increasing the previous regional income gaps. Similar to the EUS other expectations, Turkey will feel more pressure in the near future to develop new spatial regional development policies toward the achievement of more balance regional growth and socioeconomic cohesion. To CEMAT (2000), a well-balanced territorial development in Europe is also considered to strengthen local and regional democracy and human rights across the continent. Further, the CEMAT acknowledges the need for Trans-European, interregional, and transfrontier cooperation between member states as well as regional and local authorities in the areas of spatial development, while pointing out to the need for further enhancement of territorial cooperation among Western, Eastern and Central countries in order to achieve spatial cohesion in the entire continent. Hence, the EU is expected to ask for changes in the Turkish regional policies in order to accommodate the ESDP's principles and force Turkey to make its spatial development closer to those in the member states. These issues are important for the EU in that they can ultimately affect Turkey's accession costs associated with its spatial development. 
The global economy has imposed a different role on cities that were used to be consumption places in the Fordist production regime. The state actively involved in reproduction of the labor through social welfare programs and public services within the Fordist city, which functioned more as a demand center for mass-produced commodities. Today, cities are more important as the production sites (ŞENGÜL (2001: 197) and nerve centers in the global chain of exchanges. Hence, the capital accumulation and corresponding spatial injustices remain a major issue to be addressed by more radical spatial policies than the EU's ESDP and Turkish policies.

\section{Discussion and Policy Implications}

As we know globalization has led to increasing role played by regions and cities in the word economy, forcing them to compete for the same scarce resources. Strategies and policies the local governments adopt and implement in the global competition form the foundation for the current regional development policies. There has been an increasing role of centralization of financial sector and its tendency to locate in specific few large world cities that act as control and management centers, whereas production has been spread out over larger areas. This trend while tends to reshape space according to needs of the new economic order, it also increase spatial specialization based on comparative advantages through competition. Activation of local resources accompanied by ITT infrastructure, and a trained labor force has become vital part of regional development policies (DPT, 2000: 69). Although ignored by the EU and Turkey, this process also creates spatial development gaps with significant implications for the justice and equality. Unfortunately, the liberal economic order and its networks of exchanges force places to concentrate on strategies that promote economic objectives rather than social justice and serve the interests of the capital.

Therefore, building a competitive capacity of regions and cities is considered to be a sine qua non condition of the economic development strategies in this turbulent new world. At this junction of the time, space has become a much more relevant component in all socioeconomic policies. Policy outcomes are ultimately materialized in the space through institutional practices, socioeconomic activities, and the built-environment. While any policy with territorial impacts can irreversibly reconfigure the space as an object toward the realization of its own objectives, the place itself can in return become a subject and create new opportunities or disadvantages in implementations of the same policy. Later on, these spatially materialized outcomes may gradually become obstacles in the facilitation of similar socioeconomic policies and realization of their objectives. Within this context, 
in Turkey there is an urgent need for the development of a spatial perspective that will guide the development and implementation of policies with spatial impacts.

The Guiding Principles for Sustainable Spatial Development of the European Continent (GPFSSDEC) begins with a title suggesting the ultimate goal to which the EU attempts to reach: "a-10 point program for greater cohesion among the regions of Europe". The document states that the European social cohesion has to be accompanied by "sustainable spatial development policies that bring the social as well as economic requirements to be met by the territory into line with its ecological and cultural functions" (CEMAT, 2000). Under the dynamics of the free market and neo-liberal outlook of the ESDP that does not seek for radical changes in the European space, this title is likely to remain only a good wish.

Turkey, too, has to immediately prepare its own spatial development perspective and ITT policies in line with those of the EU. But, these policies should also contain additional objectives related to the spatial justice and a specific set of measures the state will pursue to balance between the capital accumulation in the territory and spatial justice. These shortcomings can later on constrain Turkey to restructure an economy based on information-intensive and high value-added production system. If Turkey sufficiently addresses these issues, it will probably become an influential and attractive state for surrounding neighbors. Geographically located at the center of Caucasian, African, European, Middle Eastern countries, Turkey has an historical opportunity to transform itself into an information or knowledge exportingcountry to its neighbors. Toward this goal, the followings should also be addressed:

- Turkey needs to develop certain spatial development guidelines consistent with those in the ESDP, including the promotion of a polycentric urban structure, growth poles in the poor regions, and ITT and transportation infrastructures that link the urban system together.

- Regional income disparities that have been increasing should be addressed through the development of a long-term regional development policy based on the principles of a national spatial development perspective. This policy should also provide a basis to integrate economic activities of all sectors and public participation.

- Presently, the GAP Administration is the only state agency organized on a regional base, whereas DPT in Ankara carries out regional development activities as the central government agency. There is a need for regional organization of state agencies that implement, monitor and control programs such as future national spatial development guidelines and structural funds. Independent activities of 
different ministries and state agencies at national and regional level should be strictly monitored and coordinated by DPT and its regional branches.

\section{Appendix A}

\section{The Content of ESDP}

Part A. Achieving the Balanced and Sustainable Development of the Territory of the EU: The Contribution of the Spatial Development Policy

- Chapter 1. The Spatial Approach at the European Level

- Chapter 2. Influence of Community Policies on the Territory of the EU

- Chapter 3. Policy Aims and Options for the Territory of the EU

- Chapter 4. The Application of the ESDP

- Chapter 5. The Enlargement of the EU: An Additional Challenge for European Spatial Development Policy

Part B. The Territory of the EU: Trends, Opportunities and Challenges

- Chapter 1. Spatial Development Conditions and Trends in the EU

- Chapter 2. Spatial Development Issues of European Significance

- Chapter 3. Selected Programmes and Visions for Integrated Spatial Development

- Chapter 4. Basic Data for the Accession Countries and Member States

The Content of GPFSSDEC

- Chapter 1. The Contribution of the Guiding Principles to the Implementation of the Social Cohesion of the Council of Europe

- Chapter 2. Spatial Development Policies in Europe: New ContinentWide Challenges and Prospects

- Chapter 3. Specific Roles of Private Sector in Spatial Development

- Chapter 4. Principles of a Spatial Planning Policy for Sustainable Development in Europe

- Chapter 5. Spatial Development Measures for Different Types of European Regions

- Chapter 6. Strengthening of Co-operation between the Member States of the Council of Europe and Participation of Regions, Municipalities and Citizens 


\section{References}

AKTT (1999), Gündem 2000: Genişleme-1999 Yil Aday Ülkeler llerleme Raporlari, Avrupa Komisyonu Türkiye Temsilciliği (Avrupa Komisyonu).

AKTT, (2000), 2000 Yıll Genişleme Stratejisi, Avrupa Komsiyonu Türkiye Temsilciliği (Avrupa Komisyonu).

ANGELL, lan (1995), "Winners and Losers in the Information Age," LSE Magazine: 10-12.

BECKMANN, Martin J. (1999), Lectures on Location Theory (Berlin: Springer).

BOARNET, Marlon G/MEDDA, Francesca (2003), "An Analysis of the Transportation and Land Use Links," the Paper Presented at Second Meeting of STELLA (Sustainable Transport in Europe and Links and Liaisions with America) Focus Group 3, (Washington, USA).

BORJA, Jordi/CASTELLS, Manuel (1997), Local and Global: Management of of Cities in the Information Age (London: Earthscan Publication Ltd).

BOYCE, Ronal Reed (1974), The Bases of Economic Geography (New York: Holt, Rinehart and Winston, Inc.).

BOZKURT, Veysel (2000), Enformasyon Toplumu ve Türkiye (Ankara: Sistem Yayıncılık, 3. Baskı).

CAMAGNI, Roberto (2003), "Regional Clusters, Regional Competencies and Regional Competition," Paper Presented at the International Conference on Cluster Management in Structural Policy-International Experiences and Consequences for Northrhine-Westfalia (Duisburg).

CAMAGNI, Roberto (1991), "Local 'Milieu', Uncertainty and Innovation Networks: Toward a New Dynamic Theory of Economic Space," CAMAGNI, Roberto (ed.), Innovation Networks (London: Belhaven Press).

CAPORASO, J. A. (1996), "The European Union and Forms of State: Westphalian, Regulatory or Post-Modern," Journal of Common Market Studies, 34 /1: 29-52.

CAPPELIN, Ricardo (1991), "International Networks of Cities," Roberto Camagni (ed.), Innovation Networks: Spatial Perspectives (London: Belhaven Press).

CASTELLS, Manuel / HALL, Peter (1997), "Technopoles: Mines and Foundries of the Informational Economy," LEGATES, Richard T./ STOUT, Fredric (eds.), The City Reader, (London: Routledge):

CASTELLS, Manuel (1977), Urban Question (London: Arnold).

CEC (1997), The EU Compendium of Spatial Planning Systems and Policies, Commission of the European Communities (Luxembourg: Office for Official Publications of the European Communities).

CEC (1991), Europe 2000: Outlook for the Development of the Community's Territory, Commission of the European Communities (Luxembourg: Office for Official Publications of the European Communities).

CEC (1994), Europe 2000+: Co-operation for European Territorial Development, Commission of the European Communities (Luxembourg: Office for Official Publications of the European Communities).

CEMAT (2000), The Guiding Principles for Sustainable Spatial Development of the European Continent, European Conference of Ministers Responsible for Regional Planning (Hanover: Council of Europe).

CHRISTALLER, Walter (1966), Central Places in Southern Germany (Prentice Hall) (Transtation: Charlisle W. Baskin).

CRAFTS, Nicolas/ VENABLES Anthony J. (2001), "Globalization in History: a Geographic Perspective, [Access 02/06/2004], http://www.proses.sciences-po.fr/documents/ Crafts_Venables_Globalisation_History.pdf. 
CSD (1999), European Spatial Development Perspective -Towards Balanced and Sustainable Development of the Territory of the EU, Commission on Spatial Development (Luxembourg: Office for Official Publications of the European Communities).

DUPUY, Alex (1998), "Thoughts on Globalization, Marxism and the Left," Latin American Perspectives, November $25:$ 55-60.

DPT (2000), Uzun Vadeli Strateji ve Sekizinci Beş Yıllık Kalkınma Plan 2001-2005 (Ankara) [Access: 19/08/2004], http://www.dpt.gov.tr.

EC (1997), The EU Compendium of Spatial Planning Systems and Policies (Regional Development Studies 28), European Commission (Luxembourg: Office for Official Publications of the European Communities).

EC (1999), ESDP European Spatial Development Perspective, European Commission, (Luxembourg) [Access: 02/06/2004], http://europa.eu.int/comm/regional_policy/sources/ docoffic/official/reports/som_en.htm

ERKUT, Gülden/ BAYPINAR, Mete Başar (2003), "EU Integration and the Change of Spatial Organization in Turkey," the Paper Presented at The 43rd Congress of the European Regional Science Association (Jyvaskyla, Finland).

ERKUT, Gülen et al. (2001), “Avrupa Birliği'ne Geçiş Sürecinde Bölge Planlama Eğitiminin Değerlendirilmesi," TMMOB Şehir Plancıları Odası/OTDÜ Şehir ve Bölge Planlama Bölümü (Eds.), Avrupa Birliği Süreci ve Planlama (Ankara: TMMOB Șehir Planciları Odası ve OTDÜ Şehir ve Bölge Planlama Bölümü): 111-125.

ESPON (2004), What is Spatial Planning?, European Spatial Planning Observatory Network [Access: 02/12/2004], http://www.espon.org.uk/spatialplanning.htm.

ESPON (2002), Enlargement of the European Union and the Wider European Perspective as Regards its Polycentric Spatial Structure, Tender to the European Spatial Planning Observatory Network (ESPON): Action 1.1.3., European Spatial Planning Observatory Network (Seweden).

ESPON (2002b), Action 1.1.3: Enlargement of the European Union and the Wider European Perspective as Regards its Polycentric Spatial Structure, the European Spatial Planning Observatory Network (Sweden).

FALUDI, Andreas (2001), "Introduction: The European Spatial Development Perspective (ESDP)," Paper Presented at American Planning Association 2001 National Planning Conference (New Orleans).

FISHMAN, Robert (1998), “Urban Utopias: Ebenezer Howard and Le Corbusier," CAMPELL, Scott/ FAINSTEIN, Susan (Eds.) Readings in Planning Theory (Malden, Mass.: Blackwell Publishers): 19-67.

FLANAGAN, William G. (1993), Contemporary Urban Sociology (Cambridge: Cambridge University Press).

GALLIANO, Danielle/ROUX, Pascale (2001), Spatial Externalities, Organization of Firm and its Adoption: the Specificities of French Agro-food Firms, Institute National de la Recherche Agronomique [Access: 03/07/2004], http://www.toulouse.inra.fr/centre/ esr/ wpRePEc/gal200115.pdf.

GEDIKLI, Bahar (2002) "Spatial Policies within the Framework of European Union and Turkish Planing System Vis-a-Vis these Policies," Paper Presented at the EURA Conference on Urban and Spatial European Policies: Levels of Territorial Government (Turrin, Italy).

GERAY, Cevat (1999), "Kırsal Kalkınma Yöneltileri, ilç̧e Yerel Yönetimi ve 'ílçe Köy Birlikleri' Önerisi," Çağdaş Yerel Yönetimler Dergisi, 8/2: 11-42.

GEZICI, Ferhan/HEWINGS, Geoffrey J. D. (2003), "Spatial Analysis of Regional Inequalities in Turkey", Paper Presented at the $4^{\text {th }}$ Congress of European Regional Science (Jvvaskyla, Finland) [Access: 06/07/2004], http://www.ersa.org/ersaconfs/ersa03/ cdrom/papers/99.pdf. 
GORDON, Richard (1994), Internationalization, Multinationalization, Globalization: Contradictory World Economics and New Spatial Division of Labor, Working Paper 94 (Santa Cruz, Ca.: University of California Center for the Study of Global Transformations).

GUTH, Micheal (2000), "From Technology Policy for Regions to Regional Technology Policy: toward a New Technology Policy in the EU," Paper Presented at The $4^{\text {th }}$ International Conference on Technology Policy and Innovation (Curitiba).

HARVEY, David (1999) Limits to Capital (London: Verso, New Edition).

HARVEY, David (1989) Conditions of Postmodernity (Oxford: Blackwell).

HARVEY, David (1973) Social Justice and the City (London: Arnord).

ISARD, Walter (1956), Location and Space-Economy (Cambridge, MA: The MIT Press).

JENSEN, Ole B. et al. (1996), "INTERREG IIC - A Loophole for Transnational Planning," Nordrevy, 5/6: $13-19$.

KATZNELSON, Ira (1993), Marxism and the City (Oxford: Clarendon Press).

KESKINOK, Çağatay (2001), "Türkiye de Kent Planlamanın Sorunlan ve Avrupa Birliği Süreci: Bir Karşıt Görüş," TMMOB Șehir Planciları Odası/OTDÜ Şehir ve Bölge Planlama Bölümü (Eds.), Avrupa Birliği Süreci ve Planlama (Ankara: TMMOB Şehir Plancilan Odası and OTDÜ Şehir ve Bölge Planlama Bölümü): 129-139.

KEYDER, C. / ÖNCÜ, A. (1994), "Globalization of a Third-World Metropolis: Istanbul in the 1980s," Review, 17/3: 383-421.

KOMORNICKI, Tomasz (2002) "Impacts of Border Regime Institutions on Transport Network Development in Case of Central and Eastem Europe," Paper Presented at the STELLA Transatlantic Thematic Network Sustainable Transport in Europe and Links and Liaisons with America, Focus Group 5 Kick-off Meeting (Brussels).

LAPPLE, Dieter (2001), "City and Region in the Age of Globalization and Digitization", German Journal of Urban Studies, 4/2 [Access: 10/04/2003], http://wuw. difu.de/index. shtml?/ publikationen/dfk/en/archiv/welcome.shtml.

LEFEBVRE, H. (1970), La Révolution Urbaine (Paris: Gallimard).

MARIN, Mehmet C. (2004), "Elektronik Küresel Mekanlar, Tele-koloniler ve Türkiye'deki Kentler, " Uludağ Üniversitesi I. Ulusal Genç Bilim Adamları Sempozyumu: Değişen Dünyada Türkiye'nin Önemi (Bursa: Uludağ Üniversitesi Rektörtüğü Kültür ve Sanat Kurulu Yayinları, No: 7, Cilt I): 251-275.

MARIN, Mehmet C. (2003), "Dijital Kentte Endüstrinin Mekansal Seçimi ve iş Ilişkilerine Yerleșim Kuramı Açısından Bir Bakış: Nike Inc. Örneği," II. Ulusal Bilgi, Ekonomi ve Yönetim Kongresi Bildiriler Kitabı (Istnabul: Kocaeli Üniversitesi IiBF ve BETA Basım Yayım Dağıtım Aş): 735-748.

MARIN, Mehmet C./ALTINTAS, Hakan (2003), "The Contribution of the Regional Development Agency (SAPRDA) to Rural Governance in Southeastern Anatolia," Paper Presented at Annual Conference of the European Group of Public Administration., The Third Meeting of the Study Group on Local Governance within the European Group of Public Adminstration (Portugal) [Access: 09/02/2004], http://www.uwe.ac.uk/ bbs/sglg/mehm.doc.

METCALFE, Jon (2001) "The European Urban Charter and its Implications for Urban Planning," TMMOB Şehir Planciları Odası/OTDÜ Şehir ve Bölge Planlama Bölümü (Eds.), Avrupa Birliği Süreci ve Planlama (Ankara: TMMOB Șehir Planclanı Odası): 139-143.

MOSS, Mitchell (1999), Telecommunications Systems and Large World Cities: A Case Study of New York [Access: 18/03/2003] http://mww.mitchellmoss.com/ books/worldcity.html.

ORAL, Yıldırım/ECEMIŞ, Sibel (2001), "Türkiye de Metropoliten Planlamanın Kurumlaşmasında Avrupa Birliği Sürecinin Olası Etkileri," TMMOB Şehir Plancılan Odası /OTDÜ Şehir ve 
Mehmet C. Marın • Spatial Development and ITT Policies as Cohesion Means in the EU and Turkey $\bullet 209$

Bölge Planlama Bölümü (Eds.), Avrupa Birliği Süreci ve Planlama, (Ankara: TMMOB Şehir Plancıları Odası and OTDÜ Şehir ve Bölge Planlama Bölümü): 157-168.

POGGI, G. (1978), The Development of the Modern State: A Sociology Introduction (Stanford, CA: Stanford University Press).

RICHARDSON, Tim/JENSEN, Ole B. (2000), "Discourses of Mobility and Polycentric Development: A Contested View of European Spatial Planning," European Planning Studies (Volume 8, No 4): 503-520.

SAWERS, Larry (1984), "New Perspectives on Urban Political Economy," TABB, William R. /SAWERS, Larry (eds.), Marixsm and the Metropolis: New Prespectives on Urban Political Economy (Oxford: Oxford University Press), 3-17.

ŞENGÜL, Tarık (2001), Kentsel Çelişki ve Siyaset: Kapitalist Kentleşme Süreçleri Üzerine Yazılar (istanbul: Demokrasi Kitaplığ)).

ŞENER, Nedim (2003), "Yok Böyle Yağma," Milliyet, 8 Haziran 2003 [Access: 28/12/2004], http://www.milliyet.com/2003/06/08/ekonomi/aeko.html

TEKELI, II Ihan (2001), Modernite Aşılırken Kent Planlaması (Ankara: İmge).

TEKELI, İthan (1984), "Ekonomik Bunalımın ve Bunalımdan Çıkmak için İzlenen Politikaların Toplumsal Sonuçları," TEKELI, ilthan (ed.), Türkiye'de ve Dünya'da Yaşanan Ekonomik Bunalım (Ankara: Yurt Yayınları).

TREANOR, Paul (2004), "Spatial Development Principles for the European Continent," [Access: 12/06/2004], http://web.inter.nl.net/users/Paul.Treanor/europlan.extra.html.

ÜNSAL, Fatma (2001), "Kentsel Planlamada Avrupa Birliği ile Uyumu Kolaylaştıracak Yenilikçi Araçlar," TMMOB Sehir Plancılan Odası and OTDÜ Șehir ve Bölge Planlama Bölümü (Eds.), Avrupa Birliği Süreci ve Planlama (Ankara: TMMOB Şehir Plancıları Odası): 145154.

ZIELONKA, Jan (2001), "How New Enlarged Borders Will Reshape the European Union," Journal of Common Market Studies, 39/3: 507-536. 